Nutrition and Critical Care 
This book is dedicated to Bernard Beaufrère, Chris Pennington, Peter Reeds and Arvid Wretlind who contributed greatly to this field and passed away during 2002. 
Nestlé Nutrition Workshop Series

Clinical \& Performance Program, Vol. 8

\section{Nutrition and Critical Care}

Editors

Luc Cynober, Paris, France

Frederick A. Moore, Houston, Tex., USA

20 figures and 28 tables, 2003 


\section{Nestec Ltd., 55 Avenue Nestlé, CH-1800 Vevey (Switzerland) S. Karger AG, P.O. Box, CH-4009 Basel (Switzerland) www.karger.com}

(C) 2003 Nestec Ltd., Vevey (Switzerland) and S. Karger AG, Basel (Switzerland). All rights reserved. This book is protected by copyright. No part of it may be reproduced, stored in a retrieval system, or transmitted, in any form or by any means, electronic, mechanical, photocopying, or recording, or otherwise, without the written permission of the publisher.

Printed in Switzerland on acid-free paper by Reinhardt Druck, Basel

ISBN 3-8055-7540-8

ISSN $1422-7584$

\section{Library of Congress Cataloging-in-Publication Data}

Nutrition and critical care / [edited by] Luc Cynober, Frederick A. Moore.

p. ; cm. - (Nestlé Nutrition workshop series. Clinical \& performance program ; v. 8)

Includes bibliographical references and index.

ISBN 3-8055-7540-8 (hard cover)

1. Critically ill-Nutrition-Congresses. I. Cynober, Luc A. II. Moore, Frederick A.,

1953- III. Nestlé Nutrition workshop series. Clinical \& performance programme ; v. 8.

[DNLM. 1. Critical Illness-Congresses. 2. Nutrition-Congresses. 3. Critical

Care-Congresses. WB 400 N97425 2003]

RC86.2.N88 2003

$615.8^{\prime} 54-\mathrm{dc} 21$

2003044604

The material contained in this volume was submitted as previously unpublished material, except in the instances in which credit has been given to the source from which some of the illustrative material was derived.

Great care has been taken to maintain the accuracy of the information contained in the volume. However, neither Nestec Ltd. nor S. Karger AG can be held responsible for errors or for any consequences arising from the use of the information contained herein. 


\section{Contents}

VII Preface

IX Foreword

XI Contributors

1 Overview on Metabolic Adaptation to Stress Baracos, V.E. (Edmonton)

15 Genetic Polymorphisms, Functional Genomics and the Host Inflammatory Response to Injury and Inflammation Feezor, R.J.; Moldawer, L.L. (Gainesville, Fla.)

39 Modulation of the Post-Burn Hypermetabolic State Lee, J.O.; Herndon, D.N. (Galveston, Tex.)

57 Nutrition Support in Critical Illness: Amino Acids Stehle, P. (Bonn)

75 Lipids and the Critically Ill Patient Calder, P.C. (Southampton)

99 Key Vitamins and Trace Elements in the Critically Ill Berger, M.M.; Chioléro, R.L. (Lausanne) 
119 What Is the Goal of Nutrition in the Intensive Care Unit? Allison, S.P. (Nottingham)

133 Enteral versus Parenteral Nutrition: Alterations in Mechanisms of Function in Mucosal Host Defenses Meyer, N.A.; Kudsk, K.A. (Madison, Wisc.)

149 Gut Dysfunction and Intolerance to Enteral Nutrition in Critically Ill Patients Moore, F.A.; Weisbrodt, N.W. (Houston, Tex.)

171 Nutrition of Premature and Critically Ill Neonates Neu, J. (Gainesville, Fla.); Huang, Y. (Shanghai)

187 Nutritional Support of Obese Critically Ill Patients Chioléro, R.L.; Tappy, L.; Berger, M.M. (Lausanne)

207 Nutritional Support in Acute Pancreatitis McClave, S.A. (Louisville, Ky)

223 Nutritional Support in Sepsis and Multiple Organ Failure Nitenberg, G. (Villejuif)

245 Nutraceuticals in Critical Care Nutrition Schmidt, H.; Martindale, R. (Augusta, Ga.)

265 Lessons from Pharmacokinetics in the Design of New Nutrition Formulas for Critically Ill Patients Cynober, L. (Paris)

279 Nutritional Support in ICU Patients: Position of Scientific Societies

Bozzetti, F.; Allaria, B. (Milan)

295 Concluding Remarks

299 Subject Index 


\section{Preface}

Over the past 30 years, nutritional support has evolved tremendously. While the beneficial effects of nutritional support have been demonstrated in specific types of patients (e.g. burns, trauma, postoperative cancer resection), it has been difficult to document improved outcomes in less homogenous populations. Intensive care unit (ICU) patients, due to their intense injury stress response, have the potential to benefit most from nutritional support. On the other hand, ICU patients, because of the complexity of their underlying diseases, are especially vulnerable to develop nutritional support-related complications. Despite considerable progress in understanding the optimal route of administration as well as the qualitative and quantitative needs of ICU patients, a lot of controversies and uncertainties exist. In fact, the exact pathophysiologic mechanisms that drive the injury stress response in ICU patients is still a subject of intense research. Over the last decade, a variety of pro- and anti-inflammatory mediators (reactive oxygen metabolites, cytokines, prostaglandins, and nitric oxide) have been identified that modulate hormonal control of nutrient flux. Most recent genomic research has identified a gene polymorphism that results in patients producing different levels of mediators following the same insult. In some, this causes dysregulation of the injury stress response which contributes to adverse outcomes.

This issue is not theoretical, but has important therapeutic implications. A variety of nutritional interventions (e.g. 'immune enhancing diets', $\beta$-blockers, antioxidants, and growth hormone) that modulate the immunoneuro-endocrionologic response to stress are being tested (by necessity in homogenous study populations) and are showing promising results. However, if they are truly modulating the injury stress response, it is quite conceivable that these therapies will be harmful in different subsets of critically ill ICU 
patients. Obviously, continued epidemiologic study of high risk patients is needed and new risk factors need to better characterized (e.g. the epidemic of obesity).

Since qualitative and quantitative requirements in critically ill ICU patients are different from normal ones, and since nutrition is emerging as an effective intervention in ICU patients, we have to look at nutrients as drugs. This means, for instance, the choice of lipids or specific amino acids (certain being immunostimulating while others might depress immunity), the avoidance of iatrogenic hyperglycemia or the intake of micronutrients must be carefully examined. Also, dose-ranging studies should be considered. Finally, knowledge of the pharmacokinetics of nutrient provided by the enteral or parenteral routes is essential.

The current era of molecular biology offers the potential to truly understand the driving mechanisms of the stress injury response. However, to maximally benefit our patients, translational research cannot be underemphasized. Also, we need to be pragmatic: excellent products disappear from the market if they are not tolerated by our patients. Moreover, we need to take advantage of the expertise of other practitioners who have interests similar to ours. National and international experts have written guidelines and consensus reports in recent years. These documents have been studied in depth resulting in a synthesis presented in the last chapter of this book. In sum, we feel that the chapters of this book and the attached discussions well reflect the outstanding meeting that we had near Paris in September 2002. This book should be of great interest and helpful to everyone working in the field. Good readings!

Luc A. Cynober, Frederick A. Moore 


\section{Foreword}

Severe metabolic alterations frequently occur in critically ill patients. If nutrition plays an important role in critical care, what are the needs for critically ill patients? Are the requirements organ- and/or age-specific? What is the best route of administration in artificial nutrition? If enteral, what exactly does the gut tolerate? In order to answer these questions and to further understand the pathogenesis of and the therapeutic implications for certain diseases, such as pancreatitis, multiple organ failure and sepsis, the topic 'Nutrition and Critical Care' was chosen for this Workshop, which took place near Paris in September 2002.

I sincerely thank the two chairmen, Prof. Luc Cynober and Prof. Frederick Moore, both outstanding experts in this field, for establishing the program and inviting as speakers the opinion leaders in the experimental and clinical field of nutrition in critically ill patients suffering from various diseases. Scientists from 20 countries contributed to the discussions that are also published in this book.

Furthermore, I would like to express my gratitude to Mrs. Isabelle Babin, Dr. Franck Arnaud-Battandier and their team from Nestlé France who provided the logistical support and their legendary French hospitality. Dr. Philippe Steenhout from the Nutrition Strategic Business Division in Vevey, Switzerland, was responsible for the scientific coordination. His cooperation with the chairpersons was essential for the success of this Workshop.

Prof. Wolf Endres, $M D$

Vice-President

Nestec Ltd, Vevey, Switzerland 

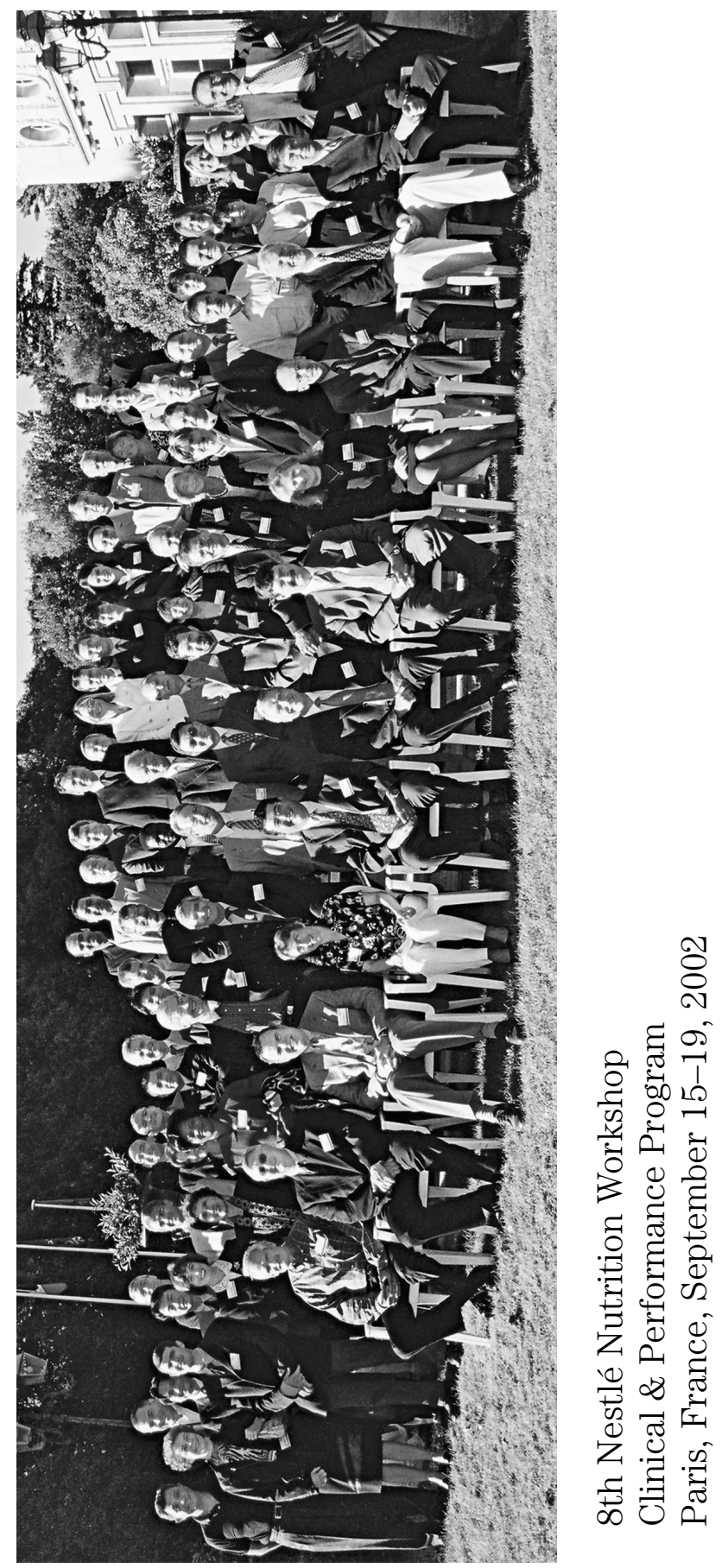


\section{Contributors}

\section{Chairpersons and Speakers}

\section{Prof. Simon P. Allison}

Clinical Nutrition Unit

University Hospital

Nottingham NG7 2UH, UK

Tel. +44 1159194427

Fax +441159194427

E-mail: simon.allison@mail.

qmcuh-tr.trent.nhs.uk

\section{Dr. Vickie E. Baracos}

Department of Agriculture, Food and Nutritional Science

University of Alberta

Edmonton, T6G 2P5

Canada

Tel. +1 7804927664

Fax +1 7804929130

E-mail: vickie.baracos@ualberta.ca

\section{Dr. Mette M. Berger}

Surgical Intensive Care Unit University Hospital (CHUV)

CH-1011 Lausanne

Switzerland

Tel. +41213142095

Fax +41213142904

E-mail:

Mette.Berger@chuv.hospvd.ch

\section{Dr. Federico Bozzetti}

Instituto Nazionale per lo Studio e la Cura dei Tumori

Divisione di Chirurgia

dell'Apparato Digerente

Via Venezian 1

I-20133 Milano, Italy

Tel. +3902 23903014

Fax +390223903011

E-mail: dottfb@tin.it

\section{Dr. Philip C. Calder}

Institute of Human Nutrition

University of Southampton

Bassett Crescent East

Southampton SO16 7PX, UK

Tel. +44238059 4223

Fax +442380595489

E-mail: pcc@soton.ac.uk

\section{Prof. René L. Chioléro}

Surgical Intensive Care Unit

University Hospital (CHUV)

CH-1011 Lausanne, Switzerland

Tel. +41213142002

Fax +41213143045

E-mail:

rene.chiolero@chuv.hospvd.ch 


\section{Prof. Luc Cynober}

Service de Biochimie A

Hôtel Dieu

1, place du Parvis Notre-Dame

F-75181 Paris Cedex 04, France

Tel. + 33142348260

Fax: +33142348612

E-mail:

luc.cynober@htd.ap-hop-paris.fr

\section{Dr. David N. Herndon}

University of Texas Medical

Branch

Shriners Hospital for Children

Department of Surgery

815 Market Street

Galveston, TX 77550, USA

Tel. +1 4097706731

Fax: +1 4097706919

E-mail: dherndon@utmb.edu

\section{Dr. Kenneth A. Kudsk}

University of Wisconsin Hospital and Clinics

Department of Surgery H4/736 Clinical Science Center 600 Highland Ave.

Madison, WI 53792-7375, USA

Tel. +1 6082631378

Fax + 16082637652

E-mail:kudsk@surgery.wisc.edu

\section{Dr. Robert Martindale}

Section of Gastrointestinal Surgery

Department of Surgery

Medical College of Georgia

1120 15th Street

Augusta, GA 30912, USA

Tel. +1 7067214686

Fax +1 7067216828

E-mail: rmartind@mail.mcg.edu

\section{Prof. Stephen A. McClave}

Division of Gastroenterology/

Hepatology

University of Louisville School of

Medicine

550 South Jackson Street

Louisville, KY 40202, USA

Tel. +1 5028526991

Fax + 15028520846

E-mail: samcclave@louisville.edu
Prof. Lyle L. Moldawer

Department of Surgery

Room 6116, Shands Hospital

University of Florida College of

Medicine

PO Box 100286

1600 SW Archer Road

Gainesville, FL 32610-0286, USA

Tel. +1 3522650494

Fax +1 3522650676

E-mail: moldawer@surgery.ufl.edu

\section{Prof. Frederick A. Moore}

Department of Surgery

University of Texas

Houston Medical School

6431 Fannin, Suite 4.264

Houston, TX 77030, USA

Tel. +1 7135007228

Fax +1 7135007232

E-mail:

frederick.a.moore@uth.tmc.edu

\section{Dr. Josef Neu}

Department of Pediatrics

University of Florida

Box J-296

1600 S.W. Archer Road

Gainesville, FL 32610, USA

Tel. +1 3523923020

Fax +1 3528463937

E-mail:neuj@peds.ufl.edu

\section{Dr. Gérard Nitenberg}

Institut Gustave Roussy

39, rue Camille Desmoulins

F-94805 Villejuif

France

Tel. +33142114506

Fax +33142115212

E-mail: nitenber@igr.fr

\section{Prof. Peter Stehle Absent}

Department of Nutrition Science

University of Bonn

Endenicher Allee 11-13

D-53115 Bonn

Germany

Tel. +49228733680

Fax +49228733217

E-mail: ehw@uni-bonn.de 


\section{Moderators}

\section{Prof. Paul Bouletreau}

Hôpital Edouard-Herriot Departement AnesthésieRéanimation

Pavillon P, Place d'Arsonval F-69437 Lyon Cedex 03, France Tel. +33472116310 Fax +33472684608

E-mail: paul.bouletreau@chu-lyon.fr

\section{Dr. Jean-Pascal De Bandt}

Faculté de Pharmacie

Laboratoire de Biologie de la Nutrition

4, avenue de l'Observatoire F-75270 Paris Cedex 06, France Tel. +33153739945 Fax +33153739948 E-mail:

debandt@pharmacie.univ-paris5.fr

\section{Prof. Pierre Déchelotte}

Hôpital Charles-Nicolle Service Polyclinique 1 , rue de Germont F-76031 Rouen Cedex, France Tel. +33232886465 Fax + 33232888357 E-mail: pierre.dechelotte@ chu-rouen.fr

\section{Dr. Raymond Peeters}

Campus Stuyvenberg

Lange Beeldekenstraat 267

B-2050 Antwerpen, Belgium

Tel. +32 32177111

Fax +32 32177360

E-mail:

md.peeters@hetgreetroussaerhuis.be

\section{Dr. Jean Fabien Zazzo}

Hôpital Antoine Béclère

Departement Anesthesie-

Réanimation

157, rue Porte de Trivaux

F-92141 Clamart Cedex, France

Tel. +33145374953

Fax +33145374342

E-mail: jfzazzo.beclere@invo.edu 


\section{Participants}

Prof. Kamal Hajiyev / Azerbaijan

Dr. Wim Fassin / Belgium

Dr. Paulo Cesar Ribeiro / Brazil

Dr. Ricardo Rosenfeld / Brazil

Dr. Daren Heyland / Canada

Dr. Khalid Hel Hilal / Dubai

Dr. Alain Bouvet / France

Dr. Cécile Chambrier / France

Dr. Elisabeth Cuchet / France

Dr. Dominique Hanon / France

Dr. Françoise Hanon / France

Dr. Dominique Jusserand / France

Dr. Florence Molenat / France

Dr. Laurent Petit / France

Dr. Jean-Marie Quintard / France

Dr. Pascal Raclot / France

Prof. Christian Löser / Germany

Dr. Ralf-Joachim Schulz / Germany

Prof. Iqbal Moestafa / Indonesia

Dr. Aris Wibudi / Indonesia

Dr. Maria Antonia Fusco / Italy

Dr. Paolo Orlandoni / Italy

Prof. Toshiaki Shimizu / Japan

Dr. Alfonso Fajardo Rodriguez /

Mexico

Dr. Fernando Molinar Ramos /

Mexico

Dr. Daniel Rodriguez Gonzalez /

Mexico

Dr. Robert Tepaske / The Netherlands

Dr. Elizabeth Kanayo Ngwu / Nigeria

Dr. Samuel Yuwa / Nigeria

Prof. Olga Maiorova / Russia

Prof. Demetre Labadarios /

South Africa

Prof. Abelardo Garcia de Lorenzo de

Mateos / Spain

Dr. Merce Planas Vila / Spain

Dr. Burapat Sangthong / Thailand

Dr. Gordon Carlson / UK

Mrs. Lynne Douglas / UK

Dr. Craig McClain / USA

Dr. Maja Djordevic / Yugoslavia

\section{Nestlé attendees}

Dr. Franck Arnaud-Battandier /

France

Mr. Laurent Freixe / France

Mr. Hervé Le Henand / France

Mr. Andreas Schläpfer / France

Mrs. Kirsten Christiani / Germany

Mr. Giorgio Giroli / Italy

Mr. Yasuhide Araki / Japan

Mrs. Patricia Anthony / Switzerland

Mr. Denis Breuille / Switzerland

Mr. Claude Cavadini / Switzerland

Prof. Wolf Endres / Switzerland

Dr. Philippe Steenhout / Switzerland

Ms. Theresa Voss / Switzerland

Mrs. Vipapan Panitantum / Thailand

Mrs. Sue Jones / UK

Mrs. Carol Siegel / USA 